\title{
PEMELIHARAAN TERIPANG PASIR (Holothuria scabra) DI KURUNGAN TANCAP
}

\author{
Anita Padang*, Eryka Lukman*, Madehusen Sangadji*, Rochman Subiyanto** \\ *Staf Pengajar FPIK-UNIDAR Ambon, $\boldsymbol{e}$-mail : - \\ **Staf Balai Perikanan Budidaya Laut Ambon, e-mail : -
}

\begin{abstract}
ABSTRAK
Budidaya perikanan adalah usaha pemeliharaan dan pengembangbiakan ikan atau organisme air lainnya di darat maupun di laut. Budidaya teripang pasir (Holothuria scabra) merupakan salah satu kegiatan budidaya perikanan guna memenuhi permintaan pasar yang terus meningkat. Kegiatan budidaya teripang pasir dapat dilakukan di alam, yaitu di kurungan tancap atau pen-culture, sehingga dapat memanfaatkan pakan diatom bentik yang tersedia secara alami. Diatom bentik dapat dirangsang pertumbuhannya dengan pemberian kotoran ayam dan daun lamun Enhalus acroides. Penelitian ini bertujuan mengetahui laju pertumbuhan dan tingkat kelulusan hidup teripang pasir yang dipelihara di kurungan tancap. Penelitian dilakukan pada perairan pantai Desa Hunut pada bulan April-September 2015. Hasil penelitian mendapatkan laju pertumbuhan teripang pasir sebesar 0,14\% dengan tingkat kelulusan hidup sebesar 92,86\%. Parameter lingkungan meliputi suhu, salinitas, $p H$, oksigen terlarut, nitrit, amoniak dan fosfat mendukung pertumbuhan teripang pasir, sedangkan nitrat termasuk rendah sehingga akan mempengaruhi pertumbuhan diatom bentik sebagai makanan teripang pasir.
\end{abstract}

Kata Kunci: Teripang Pasir, Kotoran Ayam, Daun Lamun Dan Kurungan Tancap

\section{PENDAHULUAN}

Budidaya adalah kegiatan pemeliharaan untuk memperbanyak (reproduksi), $\sqrt{ }$ menumbuhkan (growth) serta meningkatkan jumlah biota akuatik sehingga diperoleh keuntungan (Kordi, 2011). Selanjutnya Kordi (2011) juga mengemukakan bahwa budidaya perikanan adalah usaha pemeliharaan dan pengembangbiakan ikan atau organisme air lainnya termasuk teripang pasir (Holothuria scabra). Budidaya perikanan disebut juga sebagai budidaya perairan atau akuakultur mengingat organisme air yang dibudidayakan bukan hanya dari jenis ikan saja tetapi juga organisme air lain seperti teripang, kerang, udang, rumput laut maupun tumbuhan air. Akuakultur merupakan suatu proses pembiakan organisme perairan dari mulai proses produksi, penanganan hasil sampai pemasaran (Wheaton, 1977).

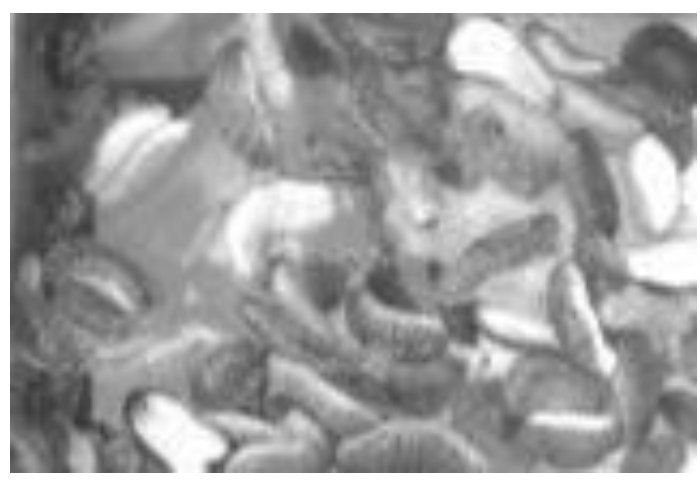

Gambar 1. Teripang pasir (Holothuria scabra) (Sumber : Data Primer, 2015) 
Budidaya teripang pasir merupakan salah kegiatan yang dapat meningkatkan pendapatan masyarakat nelayan. Namun ketersediaan pakan merupakan komponen penting dalam keberhasilan usaha budidaya terrmasuk budidaya teripang pasir. Hasil penelitian Padang $d k k$ (2014a) menunjukkan adanya pemanfaatan diatom bentik sebagai makanan teripang pasir dengan komposisi makanan dalam lambung terdiri dari Diatom/Bacillariophyceae 56\%, Cyanophyceae 4\%, Dynophyceae 1\% dan Zooplankton 39\%.

Teripang pasir merupakan komoditas $\square$ perikanan yang dapat dimakan dan dimanfaatkan sebagai bahan baku obat-obatan. Komoditas ini mempunyai prospek cerah sebagai bahan ekspor yang permintaannya terus meningkat. Data dari Badan Riset Kelautan dan Perikanan (2007) menunjukkan bahwa volume ekspor teripang pasir terus meningkat dari tahun ke tahun, terutama dalam bentuk kering dan asapan.

Eksploitasi teripang pasir yang intensif karena memiliki harga yang tinggi dimana teripang pasir dapat dimanfaatkan sebagai bahan baku obat-obatan karena mengandung protein. Kandungan protein teripang dalam kondisi basah adalah 44-55\% (Dewi, 2008) sedangkan kondisi kering adalah 82\% (Martoyo $d k k$, 2000) dan Kustiariyah (2006) teripang kering mengandung protein sebesar $34,13 \%$. Selanjutnya penelitian Padang $d k k$ (2015a) mendapatkan kandungan protein teripang pasir yang dipelihara di kurungan tancap sebesar 3,23-6,98\% (basah) dan 33,13-43,36\% (kering)

Kandungan protein yang tinggi menyebabkan teripang pasir dimanfaatkan sebagai sumber protein hewani serta dapat menyembuhkan berbagai penyakit seperti diabetes. Sebagaimana penelitian Sendih dan Gunawan (2007) dalam Karmila (2013) bahwa kandungan gizi dan bahan bioaktif yang terkandung dalam teripang dapat mengontrol glukosa darah, sehingga teripang dapat mengatasi gangguan diabetes mellitus. Selain itu teripang pasir (Holothuria scabra) juga mengandung senyawa anti bakteri (holotoksin) sehingga dapat menghambat aktivitas bakteri pathogen (Gultom, 2004; Kaswandi et al., 2000 dan Lian et al., 2000 dalam Kustiariyah, (2007) serta mempunyai khasiat pengobatan untuk berbagai penyakit (Ridzwan et al., 2005 dalam Hasan, 2013). Selanjutnya Karnila (2011); Ridhowati (2015) melaporkan bahwa bahan aktif yang dihasilkan oleh Holothuria sp sebagai antibakteri dan antikapang.

Semakin berkurangnya populasi teripang pasir di alam sedangkan permintaan pasar terus meningkat, dimana di pasar domestik dalam bentuk kering teripang pasir bernilai Rp.900.000,/kg (Hartati dkk, 2005). Hal ini diperkuat oleh penelitian Badan Riset Kelautan dan Perikanan (2007) bahwa selama ini produksi teripang umumnya diperoleh dari penangkapan di alam yang sumberdayanya semakin terbatas, sehingga untuk memenuhi volume permintaan pasar dapat ditempuh melalui usaha budidaya.

Budidaya teripang pasir di habitat aslinya di kurungan tancap (pen-culture) tidak memerlukan biaya yang besar dalam penyediaan pakan sebagaimana budidaya komoditi perikanan lainnya yang memerlukan biaya yang besar dalam penyediaan pakan. Hal ini disebabkan teripang pasir dapat memanfaatkan langsung pakan yang tersedia di alam atau dalam wadah pemeliharaan. Sebagaimana penelitian Padang $d k k$, (2014a) di perairan Suli menemukan adanya pemanfaatan fitoplankton dan zooplankton (pakan alami) sebagai makanan teripang pasir dengan komposisi terbesar yaitu fitoplankton kelas Diatom atau Bacillariophyceae sebesar $56 \%$. Dengan demikian penelitian ini bertujuan mengetahui laju pertumbuhan dan tingkat kelulusan hidup teripang pasir yang dibudidaya/dipelihara di kurungan tancap, dengan memanfaatkan pakan diatom bentik yang dirangsang pertumbuhannya dengan kotoran ayam dan daun lamun Enhalus acroides

\section{METODE PENELITIAN}

Penelitian ini dilaksanakan pada bulan April-September 2015 di perairan pantai Desa Hunut yang bersubstrat berpasir serta berada tepat di depan ekosistem mangrove dengan posisi geografis kurungan tancap yang terletak pada $03^{\circ} 38^{\prime} 01,4^{\prime \prime}$ LS dan $128^{\circ} 12^{\prime} 56,4^{\prime \prime}$ BT. Dalam wadah kurungan tancap berukuran $3 \times 3$ meter dipeliharan teripang pasir sebanyak 70 ekor dengan padat tebar mengacu pada Rustam (2006) yaitu ukuran 40 - 50 g/ekor dengan 
kepadatan 10 - 16 ekor/m²yang dikoleksi dari perairan desa Suli dengan berat rata-rata awal sebesar 66,09 gram. Dalam wadah pemeliharaan dimasukan juga kotoran ayam sebanyak $10 \mathrm{~kg}$ mengacu pada Rustam (2006) yang bertujuan \begin{tabular}{|l|l} 
merangsang pertumbuhan diatom bentik \\
\hline
\end{tabular} yang telah dilobangi dan diletakan pada setiap sudut kurungan tancap dengan komposisi masing-masing karung sebanyak $2,5 \mathrm{~kg}$ dan daun lamun Enhalus acroides yang ditanam dalam kurungan tancap sebagai habitat diatom bentik epifit (Padang, 2011; Padang, 2014b). Pengukuran berat teripang pasir dilakukan dua minggu sekali sekaligus dengan melakukan pengukuran kualitas air meliputi suhu, salinitas, oksigen terlarut, $\mathrm{pH}$, nitrat, nitrit, amoniak dan fosfat.
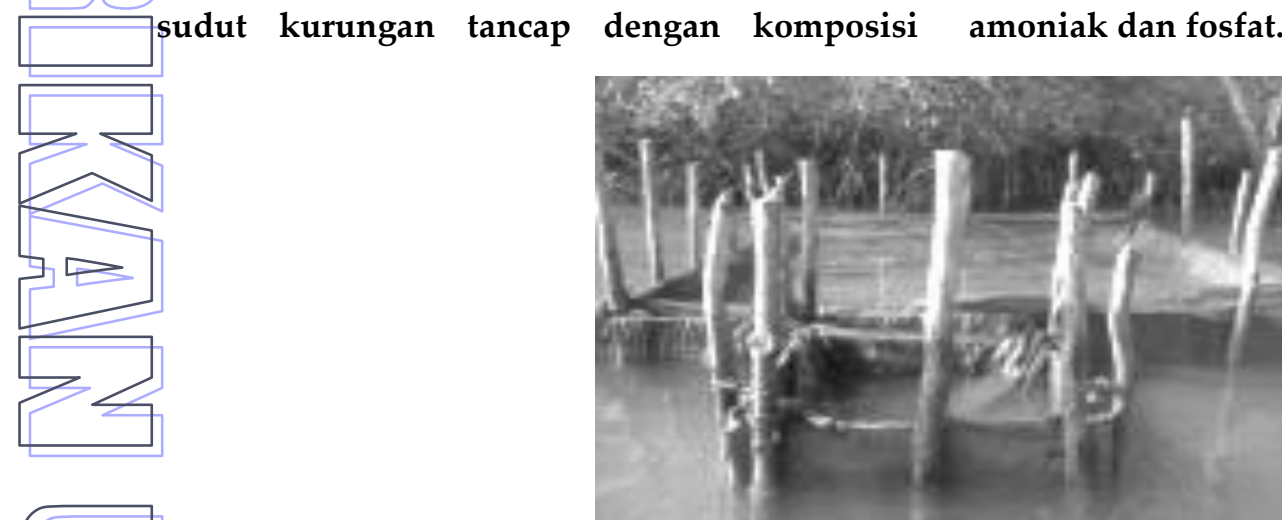

Gambar 2. Kurungan Tancap (Pen-culture) (Sumber : Data Primer, 2015)

Analisa data meliputi laju pertumbuhan dan tingkat kelulusan hidup teripang pasir. Laju pertumbuhan dianalisa berdasarkan formula menurut Buddemeier dan Kinzie (1976) dalam Supriharyono (2000) dengan rumus :

$$
G=\left(\left(\frac{W n}{W o}\right)^{1 / p}-1\right) \times 100 \%
$$

Dimana: $\mathrm{G}=$ laju pertumbuhan per hari, $\mathrm{Wn}=$ berat teripang pada hari ke $n$, Wo = berat awal teripang $\mathbf{n}=$ umur dalam hari

Tingkat Kelulusan Hidup Teripang dihitung dengan menggunakan rumus yang dikemukakan oleh (Effendi, 1979) :

$$
\mathrm{SR}=\frac{N t}{N o} x 100 \%
$$

Dimana $:$ SR $=$ Kelulusan hidup teripang $(\%), \quad$ No $=$ Jumlah teripang pada awal penelitian, $\mathrm{Nt}=$ Jumlah teripang pada akhir penelitian.

\section{HASIL DAN PEMBAHASAN}

3.1. Laju PertumbuhanTeripang Pasir

Laju pertumbuhan harian teripang pasir selama lima bulan pemeliharaan sebesar $0,14 \%$. dimana rata-rata berat pada akhir pemeliharaan sebesar 74,95gr. Ternyata teripang pasir yang dipelihara di kurungan tancap dengan pemberian daun lamun dan kotoran ayam menggalami penambahan berat harian. Hal ini mengindikasikan bahwa kotoran ayam dan daun lamun dapat merangsang pertumbuhan teripang pasir yang dipelihara. Laju pertumbuhan teripang pasir yang dipelihara di kurungan tancap lebih tinggi jika dibandingkan dengan penelitian Padang $d k k$ (2014b) dimana teripang pasir yang dipelihara di wadah terkontrol sebesar $-0,055 \%$ karena teripang pasir yang dipelihara menggalami pengurangan ukuran tubuh, hal ini diasumsikan teripang pasir kekurangan makanan dalam mendukung pertumbuhannya. Pertumbuhan teripang pasir setiap waktu pengamatan dapat dilihat pada Gambar 3.

Pertumbuhan teripang pasir termasuk lambat dimana selama 6 bulan pemeliharaan hanya terjadi penambahan berat rata-rata sebesar 8,86 gr. Sebagaimana pernyataan Purwati (2002) bahwa teripang pasir termasuk organisme yang pertumbuhannya lambat, namun ketersedian makanan akan mempercepat pertumbuhannya. sebagaimana yang dikemukakan Makanan merupakan unsur penting dalam pertumbuhan organisme termasuk teripang pasir sebagaimana 
pernyataan Effendi (1979) bahwa keberhasilan mendapatkan makanan untuk dikonsumsi akan menentukan pertumbuhan suatu organisme.

Pemeliharaan teripang pasir dalam kurungan tancap di alam memungkinkan teripang pasir lebih baik pertumbuhannya
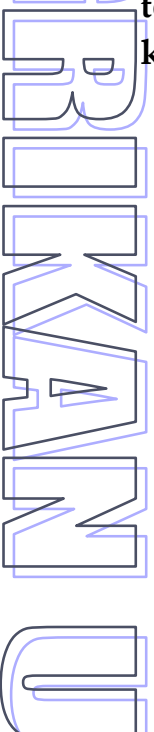
karena mendapatkan jenis makanan diatom bentik dengan prosentasi yang cukup besar, sebagaimana hasil penelitian Padang $d k k$ (2014a) teripang pasir memanfaatkan diatom bentik dalam lambungnya sebesar $56 \%$, sedangkan penelitian Padang $d k k$ (2015b) sebesar $83 \%$.

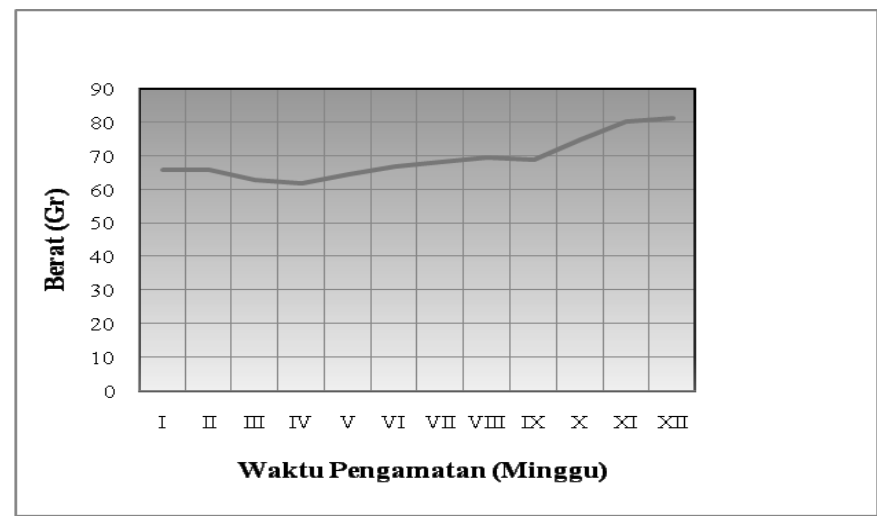

Gambar 2. Kurva Pertumbuhan Teripang Pasir (Sumber : Data Primer, 2015)

Teripang pasir merupakan organisme bentos yang cara makannya deposit feeding dapat memperoleh makanannya dari alam, berupa plankton termasuk diatom bentik (Padang $d k k, 2014 a)$. Diatom bentik merupakan fitoplankton penyumbang produktivitas primer di lingkungan bentik (Padang, 2012). Dengan demikian untuk lebih mempercepat pertumbuhan diatom bentik yang menjadi makanan teripang pasir, dapat dirangsang dengan pemberian kotoran ayam yang akan mengalami proses dekomposisi menghasilkan nitrat dan fosfat bagi pertumbuhan diatom bentik sedangkan pemberian daun lamun Enhalus acroides merupakan tempat pelekatan diatom bentik.

\subsection{Tingkat Kelulusan Hidup Teripang Pasir}

Tingkat kelulusan hidup teripang pasir sebesar $\mathbf{9 2 , 8 6 \%}$. Teripang pasir yang dipelihara sebanyak 70 ekor selama lima bulan mengalami kematian sebanyak 5 ekor. Kematian teripang pasir yang dipelihara diasumsikan karena adanya predator yaitu kepiting bakau yang masuk ke dalam wadah pemeliharan meskipun wadah pen-culture telah ditutupi oleh waring, dimana posisi kurungan tancap/pen-culture tersebut berada tepat di depan komunitas mangrove. Penelitian Padang $d k k$ (2014b) juga mendapatkan tingkat kelulusan hidup teripang pasir yang dipelihara di wadah terkontrol sebesar $97 \%$.

Kelulusan hidup teripang pasir dalam wadah kurungan tancap selain dipengaruhi oleh organisme predator juga dipengaruhi oleh parameter kualitas perairan serta ketersediaan makanan. Sebagaimana hasil penelitian Hendri dkk (2008) terhadap larva teripang pasir, ternyata makanan merupakan pendukung utama keberhasilan budidaya teripang pasir (Holothuria scabra) hingga menjadi teripang muda maupun induk. Selanjutnya penelitian Gultom (2004) juga menemukan bahwa tingkat kelulusan hidup teripang pasir di wadah pemeliharaan dipengaruhi oleh kemampuan adaptasi terhadap lingkungan perairan.

\subsection{Parameter Lingkungan}

Parameter lingkungan yang terukur selama pemeliharaan dapat dilihat pada Tabel 1.

Suhu merupakan salah satu faktor lingkungan yang penting dalam kehidupan organisme perairan. Suhu yang ditemukan pada kurungan tancap sebesar $24,8-30,5^{\circ} \mathrm{C}$ sesuai bagi kehidupan teripang pasir, sebagaimana pernyataan Martoyo dkk (2006) bahwa umumnya teripang dapat beradaptasi pada kisaran suhu $24-30^{\circ} \mathrm{C}$. Selanjutnya 
त्ञात

penelitian Padang $d k k$ (2014b) juga mendapatkan suhu pada wadah terkontrol sebesar $25,95-27,19^{\circ} \mathrm{C}$. Selain suhu pada kurungan tancap mempengaruhi pertumbuhan teripang pasir yang dipelihara, ternyata suhu juga mempengaruhi populasi diatom bentik, sebagaimana penyataan Kurniastuty (1995) dalam Astuti dkk (2012) bahwa suhu yang sesuai bagi kehidupan fitoplankton sebesar 25-30 C.

Salinitas di lokasi kurungan tancap berkisar antara 31-33,4\%o, sedangkan Padang dkk (2014b) mendapatkan salinitas di wadah terkontrol sebesar 32,03-33,59\%. Salinitas ini masih dalam kisaran optimum bagi kehidupan teripang sebagaimana dikemukakan oleh Aziz (1997) bahwa salinitas laut yang disukai teripang yaitu 30-33\%. Pernyataan lain tentang salinitas bagi teripang yaitu James et al. (1988) dalam Gultom (2004) bahwa salinitas yang ideal bagi pertumbuhan teripang yaitu 32-35\%, sedangkan Martoyo $d k k$ (2006) mengemukakan bahwa salinitas yang dapat ditolerir oleh teripang di laut yaitu sebesar 33-37\% dan di perairan pantai sebesar 32-35\%. Selanjutnya Wiboyo dkk. (1997) juga mengemukakan bahwa salinitas ideal bagi teripang sebesar 29-33\%.

Tabel 1. Parameter Lingkungan

\begin{tabular}{clcc}
\hline No & \multicolumn{1}{c}{ Parameter } & Nilai & SE \\
\hline 1. & Suhu $\left({ }^{\circ} \mathrm{C}\right)$ & $24,8-30,5$ & $\pm 0,475$ \\
2. & pH & $8,1-8,46$ & $\pm 0,033$ \\
3. & Salinitas $(\mathrm{ppm})$ & $31-33,4$ & $\pm 0,197$ \\
4. & $\mathrm{DO}(\mathrm{mg} / \mathrm{l})$ & $4,59-5,77$ & $\pm 0,097$ \\
5. & $\mathrm{NO}_{3}(\mathrm{mg} / \mathrm{l})$ & $0,028-0,075$ & $\pm 0,003$ \\
6. & $\mathrm{NH}_{3}(\mathrm{mg} / \mathrm{l})$ & $0,005-0,332$ & $\pm 0,028$ \\
7. & $\mathrm{PO}_{4}(\mathrm{mg} / \mathrm{l})$ & $0,015-0,647$ & $\pm 0,067$ \\
8. & $\mathrm{NO}_{2}(\mathrm{mg} / \mathrm{l})$ & $0,002-0,068$ & $\pm 0,005$ \\
\hline
\end{tabular}

Sumber : Data Primer 2015

Selanjutnya James et al. (1988) dalam Gultom (2004) juga mengemukakan bahwa jika terjadi kenaikan salinitas sebesar 3\% saja akan menyebabkan terjadinya pengelupasan kulit dan dalam keadaan ekstrim dapat menyebabkan kematian teripang. Dengan demikian salinitas yang ditemukan pada lokasi kurungan tancap masih sesuai bagi kehidupan teripang.

Derajat keasaman $(\mathrm{pH})$ pada kurungan tancap berkisar antara 8,1-8,46, sedangkan $\mathrm{pH}$ yang ditemukan oleh Padang $d k k$. (2014b) di wadah terkontrol sebesar 7,12-7,54. Derajat keasaman merupakan salah satu parameter lingkungan yang mempengaruhi pertumbuhan teripang pasir. Sebagaimana pendapat Ngurah (1988) dalam Bandjar dkk (1988) bahwa pertumbuhan teripang pasir juga dipengaruhi oleh $\mathrm{pH}$ perairan dimana $\mathrm{pH}$ yang cocok bagi pertumbuhan teripang yaitu $6,50-7,50$ untuk perairan produktif dan $7,50-8,50$ untuk perairan sangat produktif.

Selanjutnya Martoyo $d k k$ (2006) juga mengemukakan bahwa $\mathrm{pH}$ air laut merupakan buffer yang besar sehingga bersifat sebagai larutan penyangga yang dapat menampung asam dan basa sehingga $\mathrm{pH}$ air laut stabil, teripang bisa hidup pada kisaran $\mathrm{pH}$ 6,5- 8,5, sedangkan Wiboyo $d k k$ (1997) kisaran $\mathrm{pH}$ yang baik bagi teripang sebesar 6,8-8,5. Kisaran $\mathrm{pH}$ yang ditemukan pada kurungan tancap masih dalam kisaran yang baik untuk pertumbuhan teripang pasir serta lokasi pemeliharaan termasuk perairan yang sangat produktif.

Oksigen terlarut di perairan berasal dari difusi udara dan hasil fotosintesis tumbuhan air baik mikro (fitoplankton) maupun makro (lamun, makro alga, magrove). Oksigen terlarut sangat dibutuhkan bagi respirasi organisme di perairan termasuk teripang pasir. Kandungan oksigen terlarut pada lokasi kurungan tancap selama periode pemeliharaan sebesar 4,59-5,77 mg/l. Sedangkan penelitian Padang $d k k$ (2014b) di wadah terkontrol mendapatkan kandungan oksigen terlarut sebesar 5,74-6,86 $\mathrm{mg} / \mathrm{l}$. Kandungan oksigen terlarut pada lokasi kurungan tancap sangat mendukung pertumbuhan teripang pasir karena masih dalam kisaran optimum bagi pertumbuhan teripang, sebagaimana pernyataan Sutaman 
(1993) mengemukakan bahwa kandungan oksigen terlarut yang optimum bagi pertumbuhan teripang sebesar $3 \mathrm{mg} / \mathrm{l}$, sedangkan Martoyo $d k k$ (1994) dan Wiboyo $d k k$ (1997) sebesar 4-8 mg/l.

Konsentrasi fosfat pada kurungan tancap berkisar antara 0,015-0,647 mg/l. Fosfat merupakan nutrien penting bagi pertumbuhan fitoplankton termasuk diatom bentik yang merupakan makanan dari teripang pasir. Hasil penelitian Serang $d k k$ (2014) menemukan kadar fosfat pada lokasi pemeliharaan teripang pasir sebesar < 0,25 mg/l, selanjutnya Susilowati et al. (2004) dalam Serang dkk (2014) mengemukakan bahwa fosfat yang baik untuk pertumbuhan teripang pasir yaitu $<5 \mathrm{mg} / \mathrm{l}$. Dengan demikian konsentrasi fosfat pada lokasi penelitian masih baik bagi pertumbuhan teripang pasir.

Lokasi kurungan tancap berada di daerah pantai yang memiliki muara sungai serta berada tepat di depan ekosistem mangrove sehingga terdapat limpasan fosfat dari daratan maupun serasah tumbuhan mangrove. Hal ini diperkuat oleh pernyataan Moliber (1974) dalam Efriyeldi (1997) bahwa senyawa fosfat berasal dari erosi tanah, limpasan permukaan, buangan industri, kotoran hewan dan lapukan tumbuhan.

Selanjutnya Saeni (1989) dalam Marganof (2007) juga menyatakan bahwa fosfat yang terdapat di perairan bersumber dari air buangan penduduk (limbah rumah tangga) berupa deterjen, residu hasil pertanian (pupuk), limbah industri, hancuran bahan organik dan mineral fosfat. Kelimpahan diatom bentik sebagai makanan teripang pasir dipengaruhi oleh ketersediaan fosfat dan nitrat sebagai nutrien, sebagaimana pernyataan Nybakken (1988) bahwa terdapat dua faktor yang membatasi produktivitas fitoplankton yaitu nutrien/zat hara dan temperatur. Selanjutnya pernyataan Yuliana (2007) dalam Astuti $d k k$ (2012) bahwa terdapat keterkaitan antara kelimpahan fitoplankton dan parameter fisika kimia perairan, sedangkan kandungan ortofosfat merupakan faktor yang paling berpengaruh terhadap kelimpahan fitoplankton.

Selain fosfat, nitrat juga sangat mempengaruhi kelimpahan diatom bentik sebagai makanan teripang pasir. Konsetrasi nitrat pada lokasi kurungan tancap sebesar 0,028-0,075 mg/l. Nitrat merupakan produk akhir dari siklus nitrogen yang dapat berperan dalam mempercepat pertumbuhan tanaman termasuk diatom bentik. Menurut Welch dan Lindell (1980) dalam Efriyeldi (1997) bahwa kandungan nitrat berkisar antara 0,5-1,0 mg/l mendukung produktivitas primer perairan. Selanjutnya Nugroho (2006) mengemukakan bahwa konsentrasi nitrat yang layak bagi pertumbuhan fitoplankton di perairan adalah 0,3-13 mg/l, sedangkan Mackentum (1969) dalam Asriyana dan Yuliana (2014) yaitu sebesar 0,9-3,5 mg/1. Hasil penelitian lainnya yaitu Serang $d k k$ (2014) menemukan kadar nitrat pada lokasi pemeliharaan teripang pasir sebesar < $5 \mathrm{mg} / \mathrm{l}$, dengan demikian konsentrasi nitrat pada lokasi kurungan tancap termasuk rendah.

Amoniak merupakan salah satu bentuk dari senyawa nitrogen dan menurut Boyd (1982) tingkat toksitas amoniak tak berion berbedabeda untuk tiap spesies tetapi dengan kadar 0,6 $\mathrm{mg} / \mathrm{l}$ dapat membahayakan organisme tersebut. Konsentrasi amoniak di wadah pemeliharaan sebesar 0,005-0,332 mg/1, masih dalam batas toleransi yang tidak mempengaruhi kehidupan teripang pasir yang dibudidayakan karena memiliki konsentrasi kurang dari 0,6 mg/1.

Nitrit juga merupakan salah satu bentuk dari senyawa nitrogen yaitu bentuk peralihan antara amoniak dan nitrat (nitrifikasi). Pada perairan alami mengandung nitrit sekitar 0,001 mg/l dan yang diperbolehkan tidak boleh lebih dari $0,5 \mathrm{mg} / 1$. Kosentrasi nitrit pada lokasi penculture sebesar 0,002-0,068 mg/l, masih aman bagi kehidupan teripang pasir yang dipelihara di wadah pen-culture karena masih di bawah nilai $0,5 \mathrm{mg} / 1$.

\section{PENUTUP}

Berdasarkan hasil penelitian maka dapat disimpulkan :

1. Laju pertumbuhan harian dan tingkat kelulusan hidup teripang pasir di kurungan tancap/pen-culture cukup tinggi

2. Parameter lingkungan meliputi suhu, salinitas, $\mathrm{pH}$, oksigen terlarut, fosfat, amoniak dan nitrit mendukung pertumbuhan teripang pasir yang dipelihara 
di kurungan tancap sedangkan nitrat termasuk rendah.
UCAPAN TERIMA KASIH

Ucapan terima kasih penulis sampaikan kepada Direktorat Jenderal Pendidikan Tinggi, DP2M yang telah membiayai penelitian ini dengan dana DIPA No.023.04.1.673453/2015 Tanggal 14 November 2014.

\section{DAFTAR PUSTAKA}

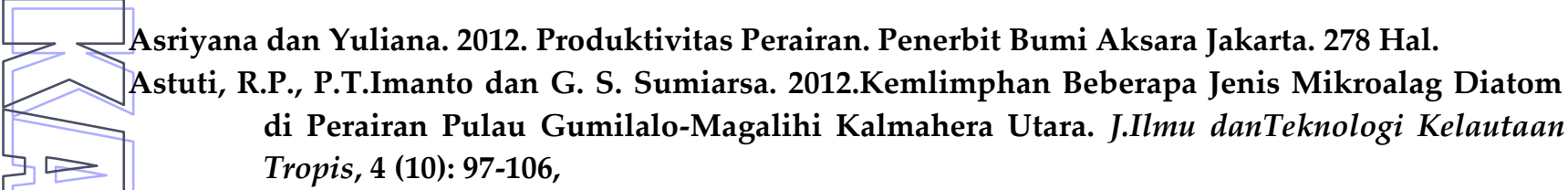

Aziz, A. 1997. Makanan dan Cara Makan Berbagai Jenis Teripang. J.Oseano, XXI (4):43-59.

Badan Riset Kelautan dan Perikanan. 2007. Analisis Data Kelautan Dan Perikann. 83 Hal

Bandjar,H.H., T.Subeki dan L.Hutuley. 1988. Kepadatan dan Berbagai Indeks Struktur Jenis Teripang (Holothuria spp) di Pantai Kulur Saparua.J. Penelitian Perikanan. 49 Hal: 99103.
Boyd, C.E. 1982. Water Quality Management for Pond Fish Culture. Elsevier Publication Ilmiah. Co. $318 \mathrm{pp}$.
Dewi, K.H. 2008. Kajian Ekstraksi Steroid Teripang Pasir (Holothuria scabra J) Sebagai Sumber Testosteron Alami Disertasi pada Pascasarjana, Institut Pertanian Bogor.Dewi, K.H.,D.Silsia.,L.Susanti.,M.Markom dan H.Mendra. Ekstraksi Teripang Pasir (Holothuria scabra) Sebagai Sumber Testosteron Pada Berbagai Kecepatan dan Lama Pengadukan. Dalam : Prosiding Seminar Nasional Teknik Kimia "Kejuangan"Pengembangan Teknologi Kimia Untuk Pengolahan Sumberdaya Alam Indonesia. ISSN : 1693-4393. Hal : 221-227

Effendi, M.I. 1979. Biologi Perikanan Penerbit Yayasan Pustaka Nusantara Yogyakarta. 163 hal.

Efriyeldi. 1997. Struktur Komunitas Makrozoobentos dan Keterkaitannya dengan Karakteristik Sedimen di Perairan Muara Sungai Bantan Tengah, Bengkalis. Tesis Pascasarjana Institut Pertanian Bogor. 102 hal.

Gultom, C.P.W. 2004. Laju Pertumbuhan dan Beberapa Aspek Ekologi Teripang Pasir (Holothuria scabra) Dalam Kolam Pembesaran di Laut Pulau Kongsi Kepualaun Seribu Jakarta Utara. Skripsi pada Program Studi Ilmu Kelautan Departemen Ilmu Teknologi Kelautan Fakultas Perikanan dan Ilmu Kelautan Institut Pertanian Bogor. 80 hal.

Hartati, R., Widianingsih dan D.Pringgenies. 2005. Teknologi Penyediaan Pakan Bagi Teripang Putih (Holothuria scabra). Laporan Kegiatan Penelitian Hibah Bersaing Universitas Diponegoro Semarang.38 hal

Hasan, H. 2013. Efek Antiurisemia Ekstrak Teripang Pasir (Holothuria scabra) pada Kelinci Jantan (Oryctolagos cuniculus). J. Entropi, 8(1): 481-487

Hendri, M., A.I.Sunaryo dan R.Y.Pahlevi. 2008. Tingkat Kelulusan Hidup Larva Teripang Pasir (Holothuria scabra, Jaeger) dengan Perlakuan Pemberian Pakan Alami Berbeda di Balai Besar Pengembangan Budidaya Laut (BBPBL) Lampung. J. Penelitian Sains 12 (1)

Karmila, A. 2013. Efek Pemberian Teripang Pasir (Holothuria scabra) Terhadap Profil Imunohistokimia Antioksida Superoksiada Dismutase (SOD) pada Pankreas Tikus Diabetes. Skripsi pada Fakultas Kedokteran Hewan Institut Pertanian Bogor.Karnila, R. 2011. Potensi Ekstrak, Hidrolisat dan Isolat Protein Teripang Pasir (Holothuria scabra J.) Untuk Menurunkan Kadar Glukosa Darah dan Memperbaiki Profil Sel Beta Pankreas Tikus Diabetes Melitus. Laporan Penelitian Hibah Bersaing Universitas Riau. 54 hal 
Kordi, M.G.H.K. 2011. Marikultur Prinsip dan Praktek Budidaya Laut. Penerbit Lily Publisher Yogyakarta. 618 hal.

Kustiariyah. 2007. Teripang Sebagai Sumber Pangan dan Bioaktif. Buletin Teknologi Hasil Perikanan X (1): 1-8

Kustiariyah. 2006. Isolasi, Karakterisasi dan Uji Aktivitas Biologis Senyawa Steroid dari Teripang Sebagai Aprodisiaka Alami (tesis) Bogor: Sekolah Pascasarjana IPB.

D Martoyo J., N. Aji dan T.Winanto. 2006. Budidaya Teripang, Edisi Revisi. Penerbit Penebar Swadaya-Jakarta. 75 hal.

Martoyo J., N. Aji dan T.Winanto. 2000. Budidaya Teripang. Penebar Swadaya. Jakarta. 69 hal.

Martoyo J., N. Aji dan T.Winanto. 1994. Budidaya Teripang. Penebar Swadaya. Jakarta. 63 hal.

Marganof. 2007. Model Pengendalian Pencemaran Perairan di Danau Maninjau Sumatera Barat. (Tesis) Pascasarjana Institut Pertanian Bogor. 181 hal.

Nugroho, A. 2006. Bioindikator Kualitas Air. Penerbit Universitas Trisakti Jakarta. 145 hal.

Nybakken, J.W. 1988. Biologi Laut Suatu Pendekatan Ekologis. Gramedia - Jakarta. 459 hal.

Padang, A., E.Lukman dan M.Sangadji. 2015a. Kandungan Gizi Teripang Pasir yang Dipelihara di Kurungan Tancap (Pen-culture). J.Neritic 6 (2). Hal : 108-112

Padang, A., E.Lukman dan M.Sangadji. 2015b. Pemanfaatan Diatom Bentik Sebagai Makanan Teripang Dalam Rangka Pengembangan Usaha Budidaya Teripang. Laporan Penelitian Hibah Bersaing. 47 hal

Padang, A., E.Lukman., M.Sangadji. 2014a. Komposisi Makanan Dalam Lambung Teripang. J. Agrikan 7 (2) Edisi 2 Bulan Oktober 2014. Hal : 26-30

Padang, A., E.Lukman., M.Sangadji. 2014b. Pemanfaatan Diatom Bentik Sebagai Makanan Teripang Dalam Rangka Pengembangan Usaha Budidaya Teripang. Prosiding Seminar Nasional Penguatan Pembangunan Berbasis Riset Perguruan Tinggi (SPP-RPT) I 2014, Vol 1, Hal : 264-270.

Padang, A. 2012. Peranan Diatom Bagi Produktivitas Primer di Lingkungan Bentik. J Bimafika 4(1): Hal: $420-424$

Padang, A. 2011. Struktur Komunitas Diatom Bentik yang Epifit pada Daun Lamun. J. Bimafika 3(1 ): 225-229

Purwati, P. 2002. Pemulihan Populasi Teripng Melalui Fission Mungkinkah. J.Oseana XXVII (1); Hal: 19-25Ridhowati, S. 2015. Profil Asam Amino dan Asam Lemak Pada Teripang Pasir (Holothuria scabra) Olahan Belitung. Dalam : Jurnal Matematika, Saint dan Teknologi Volume 16 Nomor 2 September 2015 hal 20-27.

Rustam, 2006. Pelatihan Budidaya Laut (COREMAP Fase II Kabupaten Selayar) Yayasan Mattirotasi Makasar.11 hal

Serang, A.M., S. P. T.Rahantoknam., P.Tomatala. 2014. Pengaruh Padat Tebar Terhadap Pertumbuhan Dan Sintasan Anakan Teripang Holothuria scabra. Prosiding Seminar Nasional Penguatan Pembangunan Berbasis Riset Perguruan Tinggi (SPP-RPT) I 2014, Vol 1, Hal : 277-282

Supriharyono. 2000. Pengelolaan Ekosistem Terumbu Karang. Penerbit Djambatan. Jakarta. 118 pp. Sutaman, 1993. Petunjuk Praktis Budidaya Teripang. Penerbit Kanisius. Yogyakarta. 68 pp.

Wiboyo, S., Yunizal., E.Setiabudi., M.D. Erlina dan Tazwir. 1997. Teknologi Penanganan dan Pengolahan Teripang (Holothuridea). Jakarta: IPPL Slipi. 